\title{
Evaluation of Xanthine Oxidase Inhibitory and Antioxidant Activities of Three Organs of Idat (Cratoxylum glaucum Korth.) and Correlation with Phytochemical Content
}

\author{
Dadang Juanda ${ }^{1,2}$, Irda Fidrianny ${ }^{1}$, Komar Ruslan Wirasutisna ${ }^{1}$, Muhamad Insanu ${ }^{1, *}$
}

Dadang Juanda ${ }^{1,2}$, Irda Fidrianny ${ }^{1}$, Komar Ruslan Wirasutisna', Muhamad Insanu' ${ }^{1, *}$

'Department of Pharmaceutical Biology, School of Pharmacy, Bandung Institute of Technology, Bandung, INDONESIA.

${ }^{2}$ Faculty of Pharmacy, Bhakti Kencana

University, Bandung, INDONESIA.

\section{Correspondence}

\section{Muhamad Insanu}

Department of Pharmaceutical Biology, School of Pharmacy, Bandung Institute of Technology, Jl. Ganesha10, Bandung 40132, INDONESIA.

E-mail: insanu@fa.itb.ac.id

History

- Submission Date: 27-03-2021;

- Review completed: 22-04-2021;

- Accepted Date: 27-05-2021.

DOI : 10.5530/pj.2021.13.125

Article Available online

http://www.phcogj.com/v13/i4

\section{Copyright}

(C) 2021 Phcogj.Com. This is an openaccess article distributed under the terms of the Creative Commons Attribution 4.0 International license.

\begin{abstract}
Introduction: Idat (Cratoxylum glaucum Korth.), belonging to the genus Cratoxylum, is known to contain xanthone, quinone, flavonoids, and other phenolic compounds. Objectives: to analyze total phenolic, flavonoid, antioxidant activity, and inhibitory xanthine oxidase activities of leaves, stem, and cortex of idat. Methods: Extraction of leaves, stem, and cortex of idat was carried out by reflux using n-hexane, ethyl acetate, and ethanol as a solvent. Antioxidant activity was tested by the DPPH method and calculated to get the antioxidant activity index (AAI). Determination of total phenolic and flavonoid levels by ultraviolet-visible spectrophotometry. Results: Spectrophotometers measured the inhibitory activity on xanthine oxidase in 96-well plates with allopurinol as standard. Total phenolic and flavonoid content from C. glaucum extracts varied from 6.62 to $48.77 \mathrm{~g} \mathrm{GAE} / \mathrm{g}$ extract and $1.54-25.96 \mathrm{~g} \mathrm{QE} / 100 \mathrm{~g}$ extract respectively. The ethanol extracts of leaves, stem, and cortex were very strong antioxidant activity with Antioxidant Activity Index (AAl) values 3.89; 4.55; 10.50, meanwhile AAl of ascorbic acid and quercetin 9.46 and 14.81 respectively. The $n$-hexane of stem extract had a strong xanthine oxidase inhibitory activity with the $\mathrm{IC}_{50}$ was $36.64 \mu \mathrm{g} / \mathrm{ml}$, while allopurinol was $5.02 \mu \mathrm{g} / \mathrm{ml}$. Conclusions: Total phenolic content contributed to antioxidant activity. Phenolic compounds in leaves extracts led to the xanthine oxidase inhibitory and antioxidant activities. The extract of $C$. glaucum was active as an antioxidant and potentially an inhibitor of xanthine oxidase agents.
\end{abstract}

Key words: Antioxidant, Cratoxylum glaucum, Xanthine oxidase inhibitory.

\section{INTRODUCTION}

Uric acid is formed endogenously. It is the end product of purine catabolism formed in the liver, the primary excretion in the kidney, and a small portion in the digestive system. ${ }^{1}$ Uric acid is a marker of oxidation conditions in the body, such as ischemic conditions, atherosclerosis, diabetes, and chronic liver disorders. ${ }^{2,3}$ The xanthine oxidase enzyme catalyzes the oxidation of xanthine to uric acid and hypoxanthine to xanthine. The oxidation is producing superoxide radicals like hydrogen peroxide and reactive oxygen species (ROS). ${ }^{4}$

An increase in the number of superoxide radicals can cause oxidative stress causing macro and micro complications in metabolic syndrome. ${ }^{5,6}$ Gout is a condition of high uric acid levels (hyperuricemia) in the blood that lasts for a long time. ${ }^{7}$ Allopurinol is used clinically to treat hyperuricemia and gout. But it has an undesirable effect like nephropathy, hypersensitivity, hepatitis, and skin rash. ${ }^{8}$

Cratoxylum glaucum belongs to the Hypericaceae family. C. glaucum is traditionally used to lower blood pressure, while young leaves are used in cuisine. ${ }^{9}$ Pharmacological activities showed by the genus Cratoxylum were cytotoxic, ${ }^{10-13}$ antidiabetic activity, ${ }^{14}$ antimalarials, ${ }^{15,16}$ antibacterial, ${ }^{17,18}$ anti-HIV-1, ${ }^{19}$ and antioxidant. ${ }^{20-24}$ Information related to the evaluation of antioxidant activity and xanthine oxidase inhibitory activity of C. glaucum is very limited. The present research aimed to evaluate the antioxidant and xanthine oxidase inhibitory activities of leaves, stem, and cortex of C. glaucum Korth and their correlation with total phenolic and flavonoid content.

\section{MATERIALS AND METHODS}

\section{Materials}

Xanthine, xanthine oxidase, 2,2-diphenyl-1picrylhydrazyl (DPPH), quercetin, gallic acid were obtained from Sigma-Aldrich Chemicals (St. Louise, MO, USA). The ascorbic acid buffer solution was obtained from Merck (Darmstadt, Germany) Allopurinol was purchased from TCI (Tokyo, Japan), all other reagents were analytical grade.

\section{Preparation of plant extract}

Fresh leaves, stems, and cortex of C. glaucum Korth., were collected in May 2018 from Bangka Belitung Island, Indonesia. The plant was determined at Herbarium Bogoriense of Research Center for Biology-Indonesian Institute of Sciences, Indonesia. The collected material was washed in tap water, cut, and dried at $50^{\circ} \mathrm{C}$ for two days for leaves (L) and three days for stems (S) and cortex (C). Then

Cite this article: Juanda D, Fidrianny I, Wirasutisna KR, Insanu M. Evaluation of Xanthine Oxidase Inhibitory and Antioxidant Activities of Three Organs of Idat (Cratoxy/um glaucum Korth.) and Correlation with Phytochemical Content. Pharmacogn J. 2021;13(4): 971-976. 
the crude drug (CD) was ground into powder before extraction. The phytochemical test was formed on crude drugs and extracts such as n-hexane, ethyl acetate, and ethanol using Farnsworth and Sarker's modified method. ${ }^{25,26}$ Powdered sample $100 \mathrm{~g}$ was extracted by reflux employing three solvents with increasing polarity. Extraction was started with n-hexane and repeated three times for each of them. The residue was subsequently refluxed by a similar method using ethyl acetate and ethanol. The extract was evaporated at $50^{\circ} \mathrm{C}$ under vacuum (Rotavapor R-3, Butchi', Switzerland). So, there were three n-hexane extracts (LE-1, SE-1, and CE-1), three ethyl acetate extracts (LE-2, SE2, and CE-2), and three ethanol extracts (LE-3, SE-3, and CE-3). The extract yield percentage was determined based on the crude drug.

\section{Total phenolic content (TPC)}

The total phenolic content was evaluated with a Folin-Ciolcalteu reagent adapted to Pourmorad's method. ${ }^{27}$ Each extract of $0.5 \mathrm{~mL}$ was piped into $5 \mathrm{~mL}$ Folin-Ciolcalteu reagent $10 \%$ and $4 \mathrm{~mL}$ of sodium carbonate $1 \mathrm{M}$ and incubated the mixtures for $15 \mathrm{~min}$. The absorbance was measured at wavelength $765 \mathrm{~nm}$. For each extract, the analysis was performed in triplicate. The results were reported as g gallic acid equivalents (GAE) per $100 \mathrm{~g}$ extract (g GAE/100 g) according to the calibration curve of gallic acid $40-100 \mu \mathrm{g} / \mathrm{mL}$ as standard.

\section{Total flavonoid content (TFC)}

The total content of flavonoids was measured using an adapted method from Chang. ${ }^{28}$ Each extract of $0.5 \mathrm{~mL}$ was piped into $0.1 \mathrm{~mL}$ aluminum chloride $10 \%, 0.1 \mathrm{~mL}$ sodium acetate $1 \mathrm{M}$ and $2.8 \mathrm{~mL}$ aqua dest. The mixture was diluted with $1.5 \mathrm{~mL}$ ethanol and $15 \mathrm{~min}$ incubated. At wavelength $415 \mathrm{~nm}$, the absorbance was read. For each extract, the analysis was performed in triplicate. The results were presented as $g$ equivalents quercetin (QE) per $100 \mathrm{~g}$ extract ( $\mathrm{g} \mathrm{QE} / 100 \mathrm{~g}$ ) according to the calibration curve of quercetin $50-100 \mu \mathrm{g} / \mathrm{mL}$ as standard.

\section{Antioxidant activity (AAI)}

The 2,2-diphenyl-1-picrylhydrazyl evaluated the antioxidant activity (DPPH) adapted from the modification of Blois's method..$^{29}$ Different concentrations of each sample were mixed with DPPH solution $50 \mu \mathrm{g} /$ $\mathrm{mL}$ (volume 1:1) to start the reaction to get a calibration curve. Using blank methanol and DPPH was used as a control. The standard was used as ascorbic acid and quercetin. Evaluation of absorbance was conducted at wavelength $516 \mathrm{~nm}$ by using spectrophotometer UV-Vis (Beckman Coulter DU 720) after 30 min of incubation. The experiment was done with tri replication for standard and sample.

The radical scavenging activity was calculated according to the equation; $\mathrm{I} \%=\left[\left(\mathrm{Abs}_{0}-\mathrm{Abs}_{1}\right) / \mathrm{Abs}_{0}\right] \times 100$, where $\mathrm{Abs}_{0}$ is the control absorbance and $A b s_{1}$ is the absorbance of the sample at various concentration. The $\mathrm{IC}_{50}$ (concentration that inhibits $50 \%$ of DPPH) is calculated using the calibration curve between concentration and percent inhibition. The antioxidant activity index (AAI) was determined using the equation; $\mathrm{AAI}=[$ final concentration of DPPH $(\mu \mathrm{g} / \mathrm{mL})] / \mathrm{IC}_{50}(\mu \mathrm{g} / \mathrm{mL}) .{ }^{30}$

\section{Xanthine oxidase inhibitory activity (XOI)}

The inhibitory activity on xanthine oxidase was measured by spectrophotometer in 96-well plates (Corning, UV-Transparent Clear Microplates) below the aerobic conditions, following the method reported by Owen and Duong with some modification. ${ }^{31,32}$ Dissolved the extracts in dimethyl sulfoxide (DMSO) then dilute with buffer. The final DMSO concentration was not higher than $0.5 \%$. Allopurinol was used as a standard. The test solution consisted of $50 \mu \mathrm{L}$ of the sample of extract, $35 \mu \mathrm{L}$ of phosphate buffer ( $\mathrm{pH} 7.5$ ), $30 \mu \mathrm{L}$ of freshly made solution for the enzyme $(0.2 \mathrm{unit} / \mathrm{mL}$ xanthine oxidase in phosphate buffer $\mathrm{pH} 7.5)$, then $60 \mu \mathrm{L}$ of substrate solution $(0.15 \mathrm{mM}$ of xanthine in phosphate buffer $\mathrm{pH}$ 7.5). The test solution was incubated at $25^{\circ} \mathrm{C}$ for $5 \mathrm{~min}$. The absorbance was measured at 15 minutes using a microplate reader (Tecan infinite M200 pro) at $\lambda 290 \mathrm{~nm}$. In the same procedure, a blank was prepared, but the enzyme was substituted by phosphate buffer $\mathrm{pH}$ 7.5. The analysis for allopurinol and each extract was performed in triplicate. The inhibitory activity of xanthine oxidase was determined using the formula: $\mathrm{I} \%=[(A-B) / A] \times 100$, where $A=$ absorbance of enzyme xanthine oxidase without test extract - blank of $A$ (absorbance without $\mathrm{XO}$ and test extract), $B=$ absorbance of the test extract - blank of $B$ (absorbance without $\mathrm{XO}$ ). The $\mathrm{IC}_{50}$ value was determined from the calibration curve between concentration and percent inhibition.

\section{Statistical analysis}

The results reported were the means \pm SD of at least three independent tests, using MS Excel Software, to evaluate the $\mathrm{IC}_{50}$ value. Analysis of the statistic (one-way ANOVA and post hoc Tukey) was carried out by SPSS 23. Using Pearson's method, correlations were made between the total phenolic and flavonoid content with antioxidant and xanthine oxidase inhibitory activities.

\section{RESULTS}

\section{Phytochemical screening}

Phytochemical screening was conducted to determine secondary metabolites in the leaves, stems, and cortex of C. glaucum. The screening was performed on the crude drug and extracts. The results of the phytochemical analysis were shown in Table 1. Alkaloid was not detected in all crude drugs and extracts. Flavonoids, quinones, phenols tannins, saponins, and steroids/triterpenoids were detected in the leaves and cortex's crude drug.

\section{Extraction}

The reflux method was used to extract the chemical content of $C$. glaucum, using solvents with increasing polarity. Determination of extract density was done to determine the level of viscosity of the extract used. Measurement of density was carried out on $1 \% \mathrm{w} / \mathrm{v}$ extract, and the results indicated the density of the extracts had in the range 0.62 0.91 . Table 2 showed the yield and density of extracts.

\section{Total phenolic and flavonoid content}

Total phenol content of the extract was calculated as gallic acid equivalent using the calibration curve equation $\mathrm{y}=0.0054 \mathrm{x}+0.057$; $\mathrm{R}^{2}=0.994$. Total phenol levels for each organ of C. glaucum differed in the range of 6.62 - $48.77 \mathrm{~g} \mathrm{GAE} / 100 \mathrm{~g}$ extract (Table 2). Ethanol extract for each part of the plant organ had the highest concentration than the other solvents in the range of 29.51 - $48.77 \mathrm{~g} \mathrm{GAE} / 100 \mathrm{~g}$ extract. The total phenolic content of the extract was calculated as quercetin using a calibration curve equation $\mathrm{y}=0.0067 \mathrm{x}+0.1121, \mathrm{R}^{2}=0.995$. Total flavonoid levels for each extract varied from 1.54 to $25.96 \mathrm{~g} \mathrm{QE} / 100$ g extract. SE-2 (ethyl acetate extract of the stem) had the highest total flavonoid levels (25.96 g QE/100 g), and the lowest levels (1.54 g QE/100 g) was CE-3 (ethanol extract of cortex). The results of total flavonoid content were shown in Table 2.

\section{Antioxidant activity of the extract}

Evaluation of antioxidant activity used free radicals 2,2-diphenyl-1picrylhydrazyl (DPPH), which was soluble in methanol or ethanol. It had a maximum wavelength of $\lambda 515-520 \mathrm{~nm}$. The antioxidant activity was expressed in the antioxidant activity index (AAI) showed in Table 3.

\section{Xanthine oxidase inhibitory activity}

Evaluation of xanthine oxidase inhibitory activity (XOI) from different parts of C. glaucum gave $\mathrm{IC}_{50}$ values in the range of $36.64-96.96 \mu \mathrm{g} /$ $\mathrm{ml}$ with the $\mathrm{IC}_{50}$ of allopurinol was $5.02 \mu \mathrm{g} / \mathrm{ml}$. The XOI activity of each extract can be seen in Table 3 . 
Juanda D, et al:: Evaluation of Xanthine Oxidase Inhibitory and Antioxidant Activities of Three Organs of Idat (Cratoxylum glaucum Korth.) and Correlation with Phytochemical Content

Table 1: Phytochemical screening of crude drug and extracts of $C$. glaucum.

\begin{tabular}{|c|c|c|c|c|c|c|c|c|c|c|c|c|}
\hline \multirow{2}{*}{ Phytoconstituents Tested } & \multicolumn{4}{|c|}{ Leaves of $C$. glaucum } & \multicolumn{4}{|c|}{ Stem of $C$. glaucum } & \multicolumn{4}{|c|}{ Cortex of C. glaucum } \\
\hline & $\mathrm{CD}$ & LE-1 & LE-2 & LE-3 & $C D$ & SE-1 & SE-2 & SE-3 & $C D$ & CE-1 & CE-2 & CE-3 \\
\hline Alkaloids & - & - & - & - & - & - & - & - & - & - & - & - \\
\hline Flavonoids & + & + & + & + & + & + & + & + & + & + & + & + \\
\hline Quinones & + & - & + & + & + & - & - & + & + & - & - & + \\
\hline Phenols & + & - & + & + & + & - & - & + & + & - & + & + \\
\hline Tannins & + & - & - & + & - & - & - & - & + & - & - & + \\
\hline Saponins & + & - & - & + & + & - & - & + & + & - & + & + \\
\hline Steroids/ Triterpenoids & + & + & + & + & + & + & + & + & + & + & + & + \\
\hline
\end{tabular}

$\mathrm{CD}=$ crude drug; $(+)$ detected; $(-)$ not detected, LE-1= n-hexane leaves extract, LE-2 = ethyl acetate leaves extract, LE-3 = ethanol leaves extract, SE-1=n-hexane stems extract, SE-2 = ethyl acetate stems extract, SE-3 = ethanol stems extract, CE-1=n-hexane cortex extract, CE-2 = ethyl acetate cortex extract, CE-3 = ethanol cortex extract

Table 2: Total phenolic and total flavonoid content of $C$. glaucum extracts.

\begin{tabular}{|c|c|c|c|c|}
\hline Sample & Yield (\%) & Density of Extract & $\begin{array}{c}\text { TPC } \\
(\mathrm{g} G A E / 100 \mathrm{~g})\end{array}$ & $\begin{array}{c}\text { TFC } \\
(\mathrm{g} Q E / 100 \mathrm{~g})\end{array}$ \\
\hline LE-1 & 4.61 & 0.62 & $8.89 \pm 0.02$ & $8.89 \pm 0.04$ \\
\hline LE-2 & 7.63 & 0.87 & $27.78 \pm 0.07$ & $25.28 \pm 0.03$ \\
\hline LE-3 & 16.12 & 0.76 & $35.95 \pm 0.04$ & $8.60 \pm 0.01$ \\
\hline SE-1 & 3.29 & 0.64 & $8.68 \pm 0.02$ & $20.36 \pm 0.06$ \\
\hline SE-2 & 3.26 & 0.91 & $17.88 \pm 0.04$ & $25.96 \pm 0.09$ \\
\hline SE-3 & 3.18 & 0.82 & $29.51 \pm 0.04$ & $4.92 \pm 0.02$ \\
\hline CE-1 & 2.33 & 0.69 & $6.62 \pm 0.02$ & $13.96 \pm 0.05$ \\
\hline CE-2 & 4.25 & 0.86 & $18.31 \pm 0.02$ & $17.89 \pm 0.02$ \\
\hline CE-3 & 12.84 & 0.87 & $48.77 \pm 0.11$ & $1.54 \pm 0.01$ \\
\hline
\end{tabular}

the reported values are mean $\pm \operatorname{SD}(n=3)$

Table 3: Xantin oxidase inhibitory activity and antioxidant activity in various extracts of C. glaucum.

\begin{tabular}{|c|c|c|c|}
\hline Sample & $\mathrm{IC}_{50}(\mu \mathrm{g} / \mathrm{ml})(\mathrm{XOI})$ & $\begin{array}{c}\mathrm{IC}_{50}(\mu \mathrm{g} / \mathrm{ml}) \\
(\mathrm{DPPH})\end{array}$ & $\begin{array}{c}\text { AAl } \\
\text { (DPPH) }\end{array}$ \\
\hline LE-1 & $87.06 \pm 1.47^{\mathrm{a}}$ & $16.24 \pm 0.29$ & $1.54 \pm 0.03$ \\
\hline LE-2 & $83.64 \pm 1.73^{a}$ & $7.33 \pm 0.01$ & $3.41 \pm 0.01$ \\
\hline LE-3 & $56.16 \pm 1.16$ & $6.24 \pm 0.01$ & $3.90 \pm 0.01$ \\
\hline SE-1 & $36.64 \pm 0.68^{\mathrm{b}}$ & $16.69 \pm 0.66$ & $1.50 \pm 0.06$ \\
\hline SE-2 & $69.62 \pm 2.10^{c}$ & $12.32 \pm 0.12$ & $2.03 \pm 0.02$ \\
\hline SE-3 & $96.96 \pm 2.52$ & $5.50 \pm 0.02$ & $4.55 \pm 0.02$ \\
\hline CE-1 & $37.69 \pm 4.28^{\mathrm{b}}$ & $76.78 \pm 0.06$ & $0.33 \pm 0.00$ \\
\hline CE-2 & $65.42 \pm 2.51^{c}$ & $8.70 \pm 0.06$ & $2.88 \pm 0.02$ \\
\hline CE-3 & $64.88 \pm 3.61^{c}$ & $2.38 \pm 0.01$ & $10.50 \pm 0.03$ \\
\hline Allopurinol & $5.02 \pm 0.04$ & - & - \\
\hline Ascorbic Acid & - & $2.64 \pm 0.00$ & $9.46 \pm 0.01$ \\
\hline Quercetin & - & $1.69 \pm 0.00$ & $14.81 \pm 0.02$ \\
\hline
\end{tabular}

the reported value is mean $\pm S D(n=3)$, a - $c$ with the same letter is not significant differences at $p<0.05$

Correlation between total phenolic, flavonoid, antioxidant activity index, and xanthine oxidase inhibitory in various extracts of $C$. glaucum

The high and positive correlation between AAI and total phenolic content was shown by the LE sample $(r=0.995, p<0.01)$ and also for SE and CE samples (Table 4). Total phenolic content (TPC) of leaves extract (LE) had negative and significant correlation with xanthine oxidase inhibitory activity $(\mathrm{r}=-0.795, \mathrm{p}<0.01)$. The same thing was shown by stem extract (SE), which had a negatively significant correlation with total flavonoid content $(r=-0.668 ; p<0.05)$ (Table 5). The antioxidant activity of leaves extract (LE) was negatively significant correlation with $\mathrm{IC}_{50} \mathrm{XOI}(\mathrm{r}=-0.728, \mathrm{p}<0.05)$ (Table 6).

\section{DISCUSSION}

Idat (Cratoxylum glaucum Korth.) included in the Hypericaceae family, traditionally used for joint pain, lowering blood pressure, and young leaves are used in cuisine. Based on the results of phytochemical screening did not contain alkaloids. The difference in the crude drug content was caused by the distribution of different compounds in plant organs. The solvent which is used in extraction will affect the chemical content contained in the extract. Cratoxylum genus is known to have xanthone, flavonoids, quinones, anthraquinone, steroids/triterpenoids, and phenolic compounds. ${ }^{20,33}$

Extraction was carried out by reflux with different polarity solvents. The compound in the crude drug will be derived based on polarity. For leaves and cortex, ethanol extract had the highest yield, showing its high polar compound content (Table 2).

The higher antioxidant activity is demonstrated by lower $\mathrm{IC}_{50} \mathrm{DPPH}$ or higher AAI of DPPH. The LE-1 with AAI value 1.54 and SE-1 (1.50) were classified in the category of strong antioxidant activity (AAI = $1-2)$, and n-hexane cortex extract (CE-1) was poor antioxidant with AAI value 0.33 (AAI < 0.5), meanwhile ethyl acetate and ethanol 
Table 4: Pearson's correlation coefficient of total phenolic, flavonoid, and AAI of DPPH.

\begin{tabular}{|ccc|}
\hline \multirow{2}{*}{ Antioxidant parameter } & \multicolumn{2}{c}{ Pearson's coefficient correlation $(r)$} \\
\cline { 2 - 3 } & TPC & TFC \\
\hline AAI DPPH LE & $0.995^{* *}$ & $0.298^{\text {ns }}$ \\
AAI DPPH SE & $0.958^{* *}$ & $-0.910^{* *}$ \\
AAI DPPH CE & $1.000^{* *}$ & $0.889^{* *}$ \\
\hline
\end{tabular}

Table 5: Pearson's correlation coefficient of total phenolic, flavonoid, and xanthine oxidase inhibitory $\left(\mathrm{IC}_{50} \mathrm{XOI}\right)$.

\begin{tabular}{ccc} 
Xanthine oxidase & Pearson's coefficient correlation $(r)$ \\
\cline { 2 - 3 } inhibitory parameter & TPC & TFC \\
\hline IC $_{50}$ XOI LE & $-0.795^{*}$ & $0.432^{\text {ns }}$ \\
IC $_{50}$ XOI SE & $0.991^{* *}$ & $-0.668^{*}$ \\
IC $_{50}$ XOI CE & $0.686^{*}$ & $-0.264^{\text {ns }}$
\end{tabular}

$\mathrm{IC}_{50} \mathrm{XOI}=$ xanthine oxidase inhibitory, $\mathrm{TPC}=$ total phenolic, $\mathrm{TFC}=$ total flavonoid, $\mathrm{LE}=$ sample $\mathrm{LE}, \mathrm{SE}=$ sample $\mathrm{SE}, \mathrm{CE}=$ sample $\mathrm{CE}, \mathrm{ns}=$ not significant, ${ }^{*}=$ significant at $\mathrm{p}<0.05,{ }^{* *}=$ significant at $\mathrm{p}<0.01$

Table 6: Pearson's correlation coefficient of AAI DPPH and xanthine oxidase inhibitory $\left(\mathrm{IC}_{50} \mathrm{XOI}\right)$.

\begin{tabular}{|cc|}
\hline Antioxidant parameter & Pearson's coefficient correlation $(r)$ \\
\cline { 2 - 2 } & $\mathrm{IC}_{50}$ XOI \\
\hline AAI DPPH LE & $-0.728^{\star}$ \\
AAI DPPH SE & $0.914^{\star *}$ \\
AAI DPPH CE & $0.666^{\star}$
\end{tabular}

$\mathrm{AAI}=$ Antioxidant activity index of DPPH scavenging activities, $\mathrm{IC}_{50} \mathrm{XOI}=$ xanthine oxidase inhibitory, $\mathrm{LE}=$ sample $\mathrm{LE}, \mathrm{SE}=$ sample $\mathrm{SE}, \mathrm{CE}=$ sample $\mathrm{CE}$, ${ }^{*}=$ significant at $\mathrm{p}<0.05,{ }^{* *}=$ significant at $\mathrm{p}<0.01$

extracts such as LE-2, LE-3, SE-2, SE-3, CE-2, CE-3 were very strong antioxidant activity $(\mathrm{AAI}>2)$ with $\mathrm{AAI}$ values in the range of 2.03 10.50. Ethanol cortex extract (CE-3) with AAI value 10.50 had stronger antioxidant activity than ascorbic acid with AAI value 9.46. Besides, quercetin had an AAI value of 14.81. This result is in line with research by Scherer and Godoy. ${ }^{30}$

TPC and TFC had correlated with AAI DPPH when higher TPC exposed higher AAI DPPH. A positive correlation between AAI and total phenolic content was shown by the LE sample $(r=0.995$, $\mathrm{p}<0.01$ ) following SE and CE samples (Table 4). In general, phenolic compounds have antioxidant activity due to the ability to donate electrons or as chelating metals. ${ }^{34}$ C. glaucum is known to have antioxidant activity. ${ }^{20}$ The previous researches stated that the other species (C. formosum) had antioxidant activity. ${ }^{35,36}$ Dulcisxanthone B and cochinxanthone $\mathrm{D}$ had an antioxidant activity that was isolated from C. cochinchinense. ${ }^{22,37}$ Phenolic compounds included tannins, flavonoids, and other compounds. Flavonoids with $\mathrm{OH}$ substitution on rings $\mathrm{A}$ and or $\mathrm{B}$ belong to the phenol group. ${ }^{38}$ The antioxidant activity of flavonoids was influenced by the degree of hydroxylation and other substituents found in flavonoids. ${ }^{34}$

Phenolic compounds are known to have antioxidant activity ${ }^{39,40}$ and xanthine oxidase inhibitory activity. ${ }^{41}$ Flavonoid compounds have antioxidants and an anti-inflammation. ${ }^{42}$ Total phenolic content (TPC) of leaves extract (LE) had negative and significant correlation with xanthine oxidase inhibitory activity $(\mathrm{r}=-0.795, \mathrm{p}<0.01)$. this revealed that high phenolic content would lower $\mathrm{IC}_{50} \mathrm{XOI}$, which exposed stronger xanthine oxidase inhibitory activity. The same thing was shown by stem extract (SE), which had a negatively significant correlation (Table 5) with total flavonoid content $(r=-0.668 ; p$ $<0.05$ ). The antioxidant activity of leaves extract (LE) was a negatively significant correlation with $\mathrm{IC}_{50}$ XOI $(\mathrm{r}=-0.728, \mathrm{p}<0.05)$, indicating that higher antioxidant activity in line with increases in xanthine oxidase inhibitory activity (Table 6). Phenolic compounds and flavonoids have xanthine oxidase inhibitory activity, ${ }^{43,44}$, like quercetin, myricetin, morin, kaempferol, and puerarin. ${ }^{45}$

The results showed that each organ of the plant gave a different pattern of inhibitory activity depending on the solvent used. This can be due to the differences in chemical content in each organ of C. glaucum. According to the result, it can be presumed that the total phenolic content of leaf extracts contributed to its antioxidant activity and xanthine oxidase inhibitory activity.

\section{CONCLUSIONS}

Leaves, stem, and cortex of Cratoxylum glaucum Korth. were potential as sources of natural antioxidants. The ethanol cortex extract had the most powerful AAI of DPPH than the other extracts. Total phenolic content of leaves extract gave significant and positive correlation with AAI of DPPH and significant and negative correlation with $\mathrm{IC}_{50}$ XOI. The $\mathrm{n}$-hexane stem extract had the strongest xanthine oxidase inhibitory activity with an $\mathrm{IC}_{50}$ value of $36.64 \mu \mathrm{g} / \mathrm{mL}$. Total phenolic content in leaves extracts contributed to antioxidant and xanthine oxidase inhibitory activities.

\section{ACKNOWLEDGEMENT}

The authors are thankful to the School of Pharmacy Bandung Institute of Technology for facilities support to perform this research.

\section{CONFLICTS OF INTEREST}

None.

\section{FUNDING/SUPPORT}

The research was funded by PDUPT (Directorate of Higher Education, Ministry of Research and Higher Education).

\section{REFERENCES}

1. Srikanthan K, Feyh A, Visweshwar H, Shapiro JI, Sodhi K. Systematic review of metabolic syndrome biomarkers: A Panel for early detection, management, and risk stratification in the West Virginian population. Int J Med Sci. 2016;13(1):2538 doi:10.7150/ijms.13800

2. Billiet L, Doaty S, Katz JD, Velasquez MT. Review of hyperuricemia as a new marker for metabolic syndrome. ISRN Rheumatology. 2014;2014 Article ID 852954. http://dx.doi.org/10.1155/2014/852954.

3. Mcgillicuddy FC, Moya ML, Hinkle CC, Joshi MR, Chiquoine EH, Billheimer JT, et al. Inflamation impairs reverse cholesterol transport in vivo. Vasc Med Circulation. 2009:119(8):1135-1145. doi:10.1161/CIRCULATIONAHA.108.810721.

4. Ramallo IA, Zacchino SA, Furlan RLE. A rapid TLC autographic method for the detection of xanthine oxidase inhibitors and superoxide scavengers. Phytochem Anal. 2006;17(1):15-19. doi:10.1002/pca.874

5. Folli $F$, Corradi D, Fanti $P$, Davalli $A$, Paez A, Giaccari $A$, et al. The role of oxidative stress in the pathogenesis of type 2 diabetes mellitus microand macrovascular complications: Avenues for a mechanistic-based therapeutic the role of oxidative stress in the pathogenesis of type 2 diabetes mellitus micro- and macro. Curr Diabetes Rev. 2011:7:313-324. doi:10.2174/157339911797415585.

6. Hutcheson R, Rocic P. The metabolic syndrome, oxidative stress, environment and cardiovascular disease: The great exploration. Eur J Pharmacol. 2011;668:S43-S49. doi:10.1155/2012/271028.

7. Nile SH, Ko EY, Kim DH, Keum YS. Screening of ferulic acid related compounds as inhibitors of xanthine oxidase and cyclooxygenase-2 with anti-inflammatory activity. Rev Bras Farmacogn. 2016;26(1):50-55. doi:10.1016/j.bjp.2015.08.013.

8. Lin WQ, Xie JX, Wu XM, Yang L, Wang HD. Inhibition of xanthine oxidase activity by Gnaphalium affine extract. Chin Med Sci J. 2014;29(4):225-230. doi:10.1016/S1001-9294(14)60075-4

9. Juanda D, Fidrianny I, Ruslan K, Insanu M. Overview of phytochemical compounds and pharmacology activities of Cratoxylum genus. Rasayan Chem. 2019:12:2065-2073. doi:10.31788/RJC.2019.1245303. 
10. MacHana S, Weerapreeyakul N, Barusrux S, Thumanu K, Tanthanuch W. FTIR microspectroscopy discriminates anticancer action on human leukemic cells by extracts of Pinus kesiya; Cratoxylum formosum ssp. pruniflorum and melphalan. Talanta. 2012;93:371-382. doi:10.1016/j.talanta.2012.02.058.

11. Nonpunya A, Weerapreeyakul N, Barusrux S. Cratoxylum formosum (Jack) Dyer ssp. pruniflorum (Kurz) Gogel. (Hóng yá mù) extract induces apoptosis in human hepatocellular carcinoma HepG2 cells through caspase-dependent pathways. Chin Med. 2014:9(1):1-9. doi:10.1186/1749-8546-9-12.

12. Kaewpiboon C, Boonnak N, Kaowinn S, Chung YH. Formoxanthone C, isolated from Cratoxylum formosum ssp. pruniflorum, reverses anticancer drug resistance by inducing both apoptosis and autophagy in human A549 lung cancer cells. Bioorg Med Chem Lett. 2018;28(4):820-825. doi:10.1016/j. bmcl.2017.07.066.

13. Nonpunya A, Sethabouppha B, Rufini S, Weerapreeyakul N. Cratoxylum formosum ssp. pruniflorum activates the TRAlL death receptor complex and inhibits topoisomerase I. S Afr J Bot. 2018:114:150-162. doi:10.1016/j. sajb.2017.11.003.

14. Zhou LY, Peng J Le, Wang JM, Geng YY, Zuo ZL, Hua Y. Structure-activity relationship of xanthones as inhibitors of xanthine oxidase. Molecules. 2018;23(2):1-11. doi:10.3390/molecules23020365

15. Laphookhieo S, Syers JK, Kiattansakul R, Chantrapromma K. Cytotoxic and antimalarial prenylated xanthones from Cratoxylum cochinchinense. Chem Pharm Bull (Tokyo). 2006;54(5):745-747. doi:10.1248/cpb.54.745.

16. Laphookhieo S, Maneerat W, Koysomboon S. Antimalarial and cytotoxic phenolic compounds from Cratoxylum maingayi and Cratoxylum cochinchinense. Molecules. 2009;14(4):1389-1395. doi:10.3390/molecules14041389.

17. Sompong B, Chatchanok K, Ponglimanont Chanita, Kanjana-opas Akkharawit, Kan C. Antibacterial and cytotoxic xanthones from the roots of Cratoxylum formosum. Phytochemistry. 2006;67(7):723-727. doi:10.1016/i. phytochem.2006.01.007

18. Kuvatanasuchati J, Laphookhieo S, Rodanant P. Antimicrobial activity agains periodontopathic bacteria and cytotoxic study of Cratoxylum formosum and Clausena lansium J Med Plants Res, 2011:5(25):5988-5992 doi:10.5897/ JMPR11.328.

19. Reutrakul V, Chanakul W, Pohmakotr M, Jaipetch T, Yoosook C, Kasisit J, et al. Anti-HIV-1 constituents from leaves and twigs of Cratoxylum arborescens. Planta Med. 2006;72(15):1433-1435. doi:10.1055/s-2006-951725.

20. Sim WC, Ee GCL, Lim CJ, Sukari MA. Cratoxylum glaucum and cratoxylum arborescens (Guttiferae)- Two potential source of antioxidant agents. Asian J Chem. 2011;23(2):569-572.

21. Mahabusarakam W, Nuangnaowarat W, Taylor WC. Xanthone derivatives from Cratoxylum cochinchinense roots. Phytochemistry. 2006;67(5):470-474.

22. Phuwapraisirisan $P$, Udomchotphruet S, Surapinit S, Tip-Pyang S. Antioxidant xanthones from Cratoxylum cochinchinense. Nat Prod Res. 2006;20(14):1332 1337.

23. Maisuthisakul $\mathrm{P}$, Pongsawatmanit $\mathrm{R}$, Gordon $\mathrm{MH}$. Characterization of the phytochemicals and antioxidant properties of extracts from teaw (Cratoxylum formosum Dyer). Food Chem. 2007;100(4):1620-1629. doi:10.1016/j. foodchem.2005.12.044

24. Bancha Y, Marlene MAB. Ultrasound-assisted extraction of phenolic compounds from Cratoxylum formosum ssp. formosum leaves using central composite design and evaluation of its protective ability against $\mathrm{H}_{2} \mathrm{O}_{2}$. induced cell death Ultrasound-assisted. Asian Pac J Trop Med. 2014;7(Supp 1):S497-S505. doi:10.1016/S1995-7645(14)60281-9

25. Farnsworth NR. Biological and phytochemical screening of plants. J Pharm Sci. 1966;55:874-875

26. Sarker SD, Nahar L, Methods in Molecular Biologi ${ }^{\mathrm{TM}}$ Series Editor. US: Humana press; 2013:350-358
27. Pourmorad F, Hosseinimehr SJ, Shahabimajd N. Antioxidant activity, pheno and flavonoid contents of some selected Iranian medicinal plants. Afr J Biotechnol. 2006:5(11):1142-1145. doi:10.1055/s-2007-987042

28. Chang CC, Yang MH, Wen HM, Chern JC. Estimation of total flavonoid conten in propolis by two complementary colometric methods. J Food Drug Anal. 2002;10(3):178-182.

29. Blois M. Antioxidant determinations by the use of a stable free radical. Nature 1958:181:1199-1200. doi:10.1038/1811199a0

30. Scherer R, Godoy HT. Antioxidant activity index (AAI) by the 2,2-diphenyl-1picrylhydrazyl method. Food Chem. 2009;112(3):654-658.

31. Duong NT, Vinh PD, Thuong PT, Hoai NT, Thanh LN, Bach TT, et al. Xanthine oxidase inhibitors from Archidendron clypearia (Jack.) I.C. Nielsen: Results from systematic screening of Vietnamese medicinal plants. Asian Pac J Trop Med. 2017;10(6):549-556. doi:10.1016/j.apjtm.2017.06.002

32. Owen PL, Johns T. Xanthine oxidase inhibitory activity of northeastern North American plant remedies used for gout. J Ethnopharmacol. 1999;64(2):149160. doi:10.1016/S0378-8741(98)00119-6.

33. Lian Ee GC, Mohd HN, Md Akim A, Akmal YM, Sukari MA, Rahmani M. Cytotoxic and antimicrobial xanthones from Cratoxylum arborescens (Guttiferae). Malay J Sci. 2013;32(1):53-60. doi:10.22452/mjs.vol32no1.9.

34. Heim KE, Tagliaferro AR, Bobilya DJ. Flavonoid antioxidants: Chemistry, metabolism and structure-activity relationships. J Nutr Biochem. 2002:13(10):572-584.

35. Kukongviriyapan U, Luangaram S, Leekhaosoong K, Kukongviriyapan V Preeprame S. Antioxidant and vascular protective activities of Cratoxylum formosum, Syzygium gratum and Limnophila aromatica. Biol Pharm Bull. 2007:30(4):661-666.

36. Promraksa B, Daduang J, Khampitak T, Koraneekit A, Palasap A. Anticancer potential of Cratoxylum formosum Subsp. pruniflorum (Kurz.) gogel extracts against cervical cancer cell lines. Asian Pac J Cancer Prev. 2015;16:6117-6121.

37. Udomchotphruet S, Phuwapraisirisan P, Sichaem JTS. Xanthones from the stems of Cratoxylum cochinchinense. Phytochemistry. 2012:73:148-151. doi:10.1002/mrc.3852

38. Fidrianny I, Nurfitri $H$, Sukrasno. In vitro antioxidant activities, phenolic flavonoid and carotenoid content from different polarity extracts of five citrus peels using DPPH and Cuprac method. J Chem Pharm Res. 2015;7(4):1525-1531.

39. Petkova N, Ivanova L, Filova G, Ivanov I, Denev P. Antioxidants and carbohydrate content in infusions and microwave extracts from eight medicinal plants. $J$ Appl Pharm Sci. 2017;7(10):55-61. doi:10.7324/JAPS.2017.71008.

40. Sulistyaningsih E, Amalia TY, Kartikasari R. Antioxidant and antimalarial activity of Leea indica leaf extract against malaria-mice model. J Appl Pharm Sci. 2017;7(12):163-168. doi:10.7324/JAPS.2017.71223

41. Ryu HW, Lee JH, Kang JE, Jin YM, Park KH. Inhibition of xanthine oxidase by phenolic phytochemicals from Broussonetia papyrifera. J Korean Soc Appl Biol Chem. 2012;55(5):587-594. doi:10.1007/s13765-012-2143-0

42. Marzocchella L, Fantini M, Benvenuto M, Masuelli L, Tresoldi I, Modesti A et al. Dietary flavonoids: Molecular mechanisms of action as anti- inflammatory agents. Recent Pat Inflamm Allergy Drug Discov. 2011;5(3):200-220. doi:10.2174/187221311797264937

43. Dong $Y$, Huang $H$, Zhao $M$, Sun-Waterhouse $D$, Lin L, Xiao $C$. Mechanism underlying the xanthine oxidase inhibitory effects of dietary flavonoids galangin and pinobanksin. J Funct Foods. 2016;24:26-36. doi:10.1016/j.jff.2016.03.021

44. Nagao A, Seki M, Kobayashi H. Inhibition of xanthine oxidase by flavonoids Biosci Biotechnol Biochem. 1999;63(10):1787-1790. doi:10.1271/bbb.63.1787

45. Mo SF, Zhou F, Lv YZ, Hu QH, Zhang DM, Kong LD. Hypouricemic action of selected flavonoids in mice: Structure-activity relationship. Biol Pharm Bull. 2007;30(8):1551-1556. doi:10.1248/bpb.30.1551 


\section{GRAPHICAL ABSTRACT}

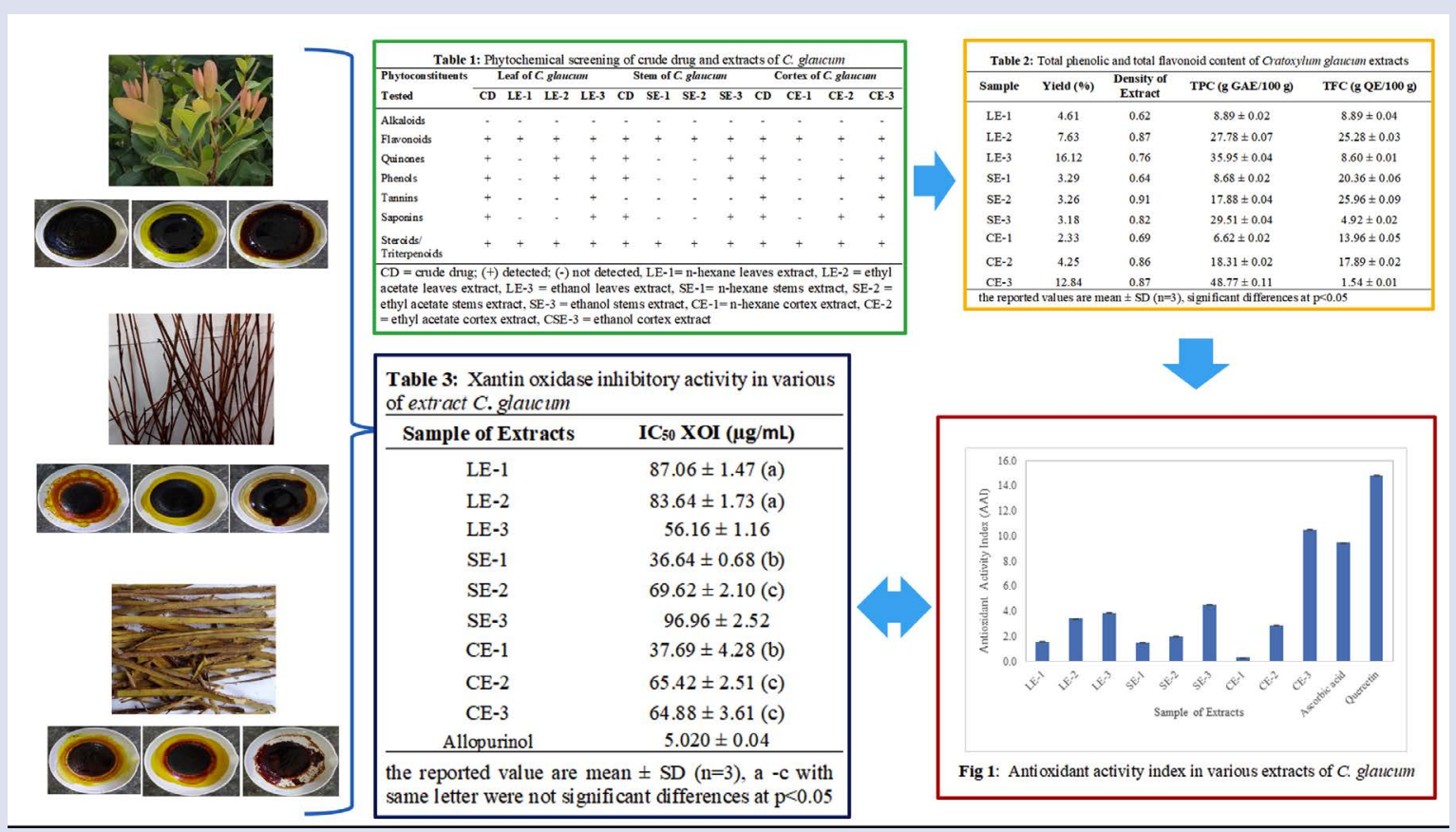

\section{ABOUT AUTHORS}

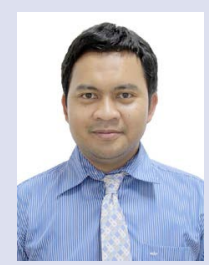

Dr. Muhamad Insanu is an Associate Professor at the Department of Pharmaceutical Biology, School of Pharmacy, Bandung Institute of Technology. His research focuses on the isolation and characterization of a natural product by activity guidance, standardization, antioxidant, antimicrobial activity, and inhibitory enzymatic reaction.

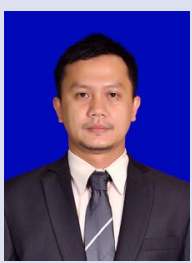

Dadang Juanda is a Ph.D. student at the School of Pharmacy Bandung Institute of Technology. His research topic is isolation and characterization of natural products from Cratoxylum glaucum guided by activity.

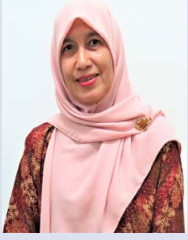

Dr. Irda Fidrianny is a Professor of Phytochemistry at School Pharmacy, Bandung Institute of Technology. She teaches phytochemistry, phytopharmaceutical technology, pharmacognosy, separation methods of natural products, and production and standardization of natural products. Her focus research is isolation and characterization a natural product by guidance activity, standardization, antioxidant, antimicrobial activity, and inhibitory enzymatic reaction. She has published over 100 research articles.

Dr. Komar Ruslan, is a Professor at School Pharmacy, Bandung Institute of Technology. His focus research is isolation and characterization of natural product.

Cite this article: Juanda D, Fidrianny I, Wirasutisna KR, Insanu M. Evaluation of Xanthine Oxidase Inhibitory and Antioxidant Activities of Three Organs of Idat (Cratoxylum glaucum Korth.) and Correlation with Phytochemical Content. Pharmacogn J. 2021;13(4): 971-976. 